\title{
THE IMPACT OF EXTENSION INTENSITIES ON INCOME OF SHEEP PRODUCERS IN THE EASTERN CAPE PROVINCE OF SOUTH AFRICA
}

\author{
Ngqulana, A. ${ }^{1}$ and Obi, A \\ Corresponding Author: A. Ngqulana, Email address: ngqulana1@ gmail.com
}

\begin{abstract}
Agricultural extension remains a key strategy for dissemination of improved agricultural technologies, yet its effectiveness is related to the level of engagement with farmers. The aim of this study was to analyse the impact of extension intensities on income of sheep producers in the Eastern Cape Province of South Africa. The study employed a cross-sectional research design and purposive sampling technique to select 105 sheep producing households who had differing degrees of exposure to the extension service in terms of the frequency of visits they hosted. The results showed that the extension intensity did not seem to have played an important role in the level of income of the households that raised and sold sheep. While this is a reflection of the fact that the existing extension services are delivered to groups rather than individual farmers, whereas farming occurs at the individual level, it is probable that measurement of the extension engagement could be an issue. Whatever the case is, the study recommends the use of other extension methods, such as face-to-face interactions, demonstrations, and more frequent visits by the extension officers, which would improve the extension effects, thus allowing the modification of the methodology to quantify the level of extension intensity employed.
\end{abstract}

Keywords: Agricultural extension, sheep producers, Eastern Cape

\section{INTRODUCTION}

Due to its semi-arid climatic conditions, South Africa's agriculture is dominated by livestock production (Cloete et al., 2014:1; Swanepoel, Stroebel \& Moyo, 2010:5). In a country where just about $16.5 \%$ of the arable land is suitable for arable agriculture, it is inevitable that crop production will constitute a mere adjunct to livestock production in circumstances where limited resources impose limits on the extent to which intensification can take place. As is well known, in the former homeland areas of the country, smallholder farmers are characterised by their pronounced resource-poverty and low skills which mean that they must rely almost exclusively on low-input enterprises. This explains the popularity of small ruminants over much of the former homelands where limited precipitation also constrains investment in large stock (Cloete et al., 2014:1). According to Rust and Rust (2013:1), small ruminant livestock are very hardy animals that can survive a wide range of climatic conditions and low input levels which make them attractive to poor farmers.

Sheep has a particularly important role to play in the socio-economic and cultural lives of South Africa (Bettencourt et al., 2013:1). Cultural activities that include slaughtering animals as sacrifice to ancestors constitute a major motivation for production and sales of sheep (Randolph et al., 2007:2). According to the Commission on the Rights of Culture and Religion (CRCR) (2011), "in African tradition, an animal could be slaughtered to give thanks, to ask for healing,

\footnotetext{
${ }^{1}$ Department of Agricultural Economics \& Extension, University of Fort Hare, Private Bag X1314, Alice 5700.
} 
S. Afr. J. Agric. Ext.

Vol. 47 No. 1, 2019: 54 - 60

http://dx.doi.org/10.17159/2413-3221/2019/v47n1a489
Ngqulana \& Obi

(License: CC BY 4.0)

to communicate with God and ancestors for a blessing and good luck, and to ask for rain or protection". The fact that these practices are embedded in strongly held beliefs means that the potential for livestock production and sales will remain high. According to Munyai (2012: 4), sheep production is the most practised enterprise in the Eastern Cape, especially in the former Transkei homeland area. For this reason, increasing livestock production while at the same time safeguarding resource bases (soil, water and air), and achieving a sustainable improvement in the standard of living of many livestock producers, is a major goal of agricultural development in the area.

However, profitable sheep production and marketing are hampered by a wide range of factors. According to Bettencourt et al. (2013:3), disease, feed shortage, poor housing and a plethora of inappropriate management practices lead to low returns to sheep producers in the communal systems of South Africa. Lack of veterinary support services and limited grazing areas have also been identified as a key constraint to expansion of sheep production and productivity (Munyai, 2012:4).

In an earlier study conducted in the Eastern Cape Province, Mapiliyao (2010:26) identified shortage of feed, disease and parasite as the most important constraints to sheep production in two villages in the Amathole District Municipality. According to Musemwa et al. (2008:239), in order to improve sheep production in the communal areas it is inevitable that farmers must adopt new and improved technologies, particularly those that entail fast growing exotic breeds. This will help to produce breeds that are highly resistant to the harsh conditions found in many rural communities in South Africa (Musemwa et al., 2008:239).

However, in their enquiry into the multifunctional role of livestock in development countries, within the framework of the World Conference on Animal Production, Swanepoel et al. (2010) observed that most small-scale farmers often fail to take up technologies developed by research. One reason advanced by these authors for this situation is that these farmers often do not have any economic incentive to do so (Swanepoel et al., 2010), but this may be only a small part of a larger range of causes. In a multi-country assessment of five countries including South Africa, Lado (1998) opined that understanding the reasons for low uptake of available technologies will require the examination of the "whole process of research, development, dissemination and utilisation of agricultural technology".

This paper focuses on one of those factors, namely dissemination of the technologies through agricultural extension services. According to Van Niekerk et al. (2011:5), the public extension service in the Eastern Cape Province is in vital need of revitalisation if it is to transform the unproductive smallholder-agriculture sector into a more commercially-orientated sector. The public extension in the region is delivered by the government agencies or advisors who assist farm people in rural communities (Zwane, 2012:18). Ntshangase, Muroyiwa and Sibanda (2018) and Ballabh (2007) found that extension intensity mattered. However, most existing studies have focused disproportionately on extension effectiveness largely in terms of administrative and financial management. The impact on household income and welfare has not been similarly examined in a systematic manner especially for the more remote parts of the province where farming remains the most important livelihoods pursuits. This paper attempts to fill that research gap and determine the impact of extension intensities on household income. 


\section{LITERATURE REVIEW AND THEORETICAL CONTEXT}

In order for extension agents to achieve the extension objectives, different extension approaches and methods are used to disseminate information on the practical tips and improved technologies for achieving improved agricultural output (Ariyo et al., 2013:19). The effectiveness of a particular method depends on how well it is aligned to the circumstances of the farmer, and Okunade (2007:282) identifies three broad categories of extension methods, namely individual method, group method and mass method. In the Eastern Cape Province of South Africa, indication is that the group contact method is dominant (Makapela, 2015:61). In such a situation, what might be important is whether or not there is extension contact and how often that happens (Cawley et al., 2015:3). A number of studies (Abdu-Raheem, 2015:16; Anderson \& Feder, 2004:1-2; Bitzer, 2016:4; Läpple \& Hennessy, 2014:2) suggest a positive relationship between extension engagement/contact and farm performance.

\section{METHODOLOGY}

\subsection{Study area, methods and material}

The study was conducted in Nyandeni Local Municipality (NLM) in the Eastern Cape Province of South Africa. The Local Municipality was selected for this study because sheep production is a mainstay of the rural economy and constitutes the key livelihoods activity in the area. The study employed a cross-sectional research design and purposive sampling technique to select 105 sheep producing households who had differing degrees of exposure to extension services in terms of the frequency of visits they hosted. Primary data were collected by means of structured interviews. Based on the assumption that a positive relationship exists between extension contact and household income, an OLS model was fitted as follows to predict a linear relationship:

$$
y_{1}=\beta_{0}+\beta \chi+v_{1}
$$

Where $y_{1}$ represents the unbiased estimate of the dependent variable (total income), $\beta_{j}$ is the estimated parameter coefficient, $X$ is the vector of the explanatory variables, and $v_{1}$ is the error term.

\section{RESULTS AND DISCUSSION}

Table 1 presents the descriptions and summary statistics of the resulting data.

Table 1: Data description and summary statistics

\begin{tabular}{|l|c|c|c|c|}
\hline \multicolumn{1}{|c|}{ Variables } & Minimum & Maximum & Mean & $\begin{array}{c}\text { Std. } \\
\text { Deviation }\end{array}$ \\
\hline INCOME & 600 & 12700 & 2133.81 & 1598.730 \\
\hline EXTENSION SERVICES & 0 & 1 & .18 & .387 \\
\hline GENDER & 0 & 1 & .55 & .500 \\
\hline AGE & 26 & 85 & 61.14 & 12.439 \\
\hline $\begin{array}{l}\text { LAND USED FOR } \\
\text { CROPPING }\end{array}$ & .0 & 3.0 & 1.329 & .5485 \\
\hline SPAZA SHOPS & 0 & 4500 & 63.81 & 462.669 \\
\hline
\end{tabular}


S. Afr. J. Agric. Ext.

Vol. 47 No. 1, 2019: 54 - 60

http://dx.doi.org/10.17159/2413-3221/2019/v47n1a489
Ngqulana \& Obi

(License: CC BY 4.0)

\begin{tabular}{|l|c|c|c|c|}
\hline $\begin{array}{l}\text { SOURCES OF INCOME } \\
\text { (Formally employed) }\end{array}$ & 0 & 15000 & 544.76 & 2202.227 \\
\hline $\begin{array}{l}\text { SOURCES OF INCOME } \\
\text { (Pension) }\end{array}$ & 0 & 3200 & 938.46 & 822.535 \\
\hline STOCK THEFT & 0 & 1 & .94 & .233 \\
\hline $\begin{array}{l}\text { LAND USED FOR } \\
\text { GRAZING }\end{array}$ & 12.0 & 14.1 & 13.415 & .6457 \\
\hline EDUCATIONAL LEVEL & 1 & 4 & 2.90 & 1.200 \\
\hline EMPOYMENT STATUS & 1 & 4 & 2.07 & .593 \\
\hline HOUSEHOLD SIZE & 3 & 16 & 7.90 & 3.185 \\
\hline $\begin{array}{l}\text { SOURCES OF INCOME } \\
\text { (Remittance) }\end{array}$ & 0 & 2500 & 169.52 & 400.810 \\
\hline $\begin{array}{l}\text { MAIZE GROWN PER } \\
\text { HACTATE }\end{array}$ & .0 & 1.7 & .647 & .2811 \\
\hline
\end{tabular}

\section{Source: Field Survey, 2017}

The results of the OLS regression using the foregoing data are presented in Table 2.

Table 2: Contribution of sheep production to household income

\begin{tabular}{|c|c|c|c|c|}
\hline Variables & $\mathbf{B}$ & Standard Error & $\mathbf{T}$ & $\mathbf{P}$ \\
\hline (Constant) & 37.173 & 187.338 & -0.198 & 0.843 \\
\hline GENDER & 17.852 & 50.132 & 0.356 & 0.723 \\
\hline AGE & -4.480 & 2.064 & -2.171 & $0.032 * *$ \\
\hline MARITAL STATUS & 11.448 & 38.708 & 0.296 & 0.768 \\
\hline EDUCATIONAL LEVEL & 52.136 & 23.142 & 2.253 & $0.027 * *$ \\
\hline HOUSEHOLD SIZE & 11.727 & 6.428 & 1.824 & $0.041 * *$ \\
\hline SHEEP SOLD & 1173.587 & 31.567 & 37.177 & $0.000 * * *$ \\
\hline SHEEP PRICE & 0.212 & 0.087 & 2.433 & $0.017 * * *$ \\
\hline ACCESS TO EXTENSION SERVICES & 16.739 & 50.245 & 0.333 & 0.740 \\
\hline NUMBER OF SHEEP DIED & -10.231 & 8.217 & -1.245 & 0.216 \\
\hline SOCIAL STATUS & -36.567 & 54.631 & -0.669 & 0.505 \\
\hline $\mathrm{F}$ & 364.529 & & & \\
\hline $\mathrm{P}$ & 0.000 & & & \\
\hline R Square & 0.978 & & & \\
\hline Adjusted R Square & 0.975 & & & \\
\hline
\end{tabular}

\section{Source: Field Survey, 2017}

According to Table 2, the overall model shows a $98 \%$ fit which suggests that most of the variations in household income are explained by the model although individual contributions of the variables tell a different story. The crucial revelation is that extension did not seem to have contributed meaningfully to the level of household income. From the results, the sheep sales and sheep prices are the most influential. This would suggest that the extension service did not exert detectable impact on the performance of the sheep producers. This clearly means that age affects sheep sales negatively as sheep farming is mostly practised by older people whilst younger people or youth are less involved in sheep production. This was supported by Kimaro, Towo and Moshi (2015:3) who pointed out that very few young people are interested 
in agriculture as young people living in rural communities are forced to migrate to urban areas or cities to seek a better standard of living.

Educational level has a positive influence on household income from sheep sales and is significant at the 5\% level. This means that the higher the educational level, the higher the number of sheep produced and subsequently the higher the sales. In addition, more educated farmers are not reluctant in adoption of new technologies they tend to be early adopters than less. According to Mwangi and Kariuki (2015:212), this is because higher education influences the respondents' attitude, allowing them to be more open, rational, and having the ability to analyse the benefits and gains of new technology, which improves production and subsequently influences sales.

Household size was also shown to have a positive influence on sheep income. This means that larger households realise larger sheep income probably because the sheep production activities are distributed among family members whose collective endeavours ensure that the relevant operations are performed timeously. In their study, Cherdchuchai and Otsuka (2006:410) noted that the size of household has practical implications for labour availability.

Sheep sales, and by extension, sheep prices, are expected to make an important contribution to household income which turned out to be the case in the present study which showed a strong positive relationship between sheep sales and the income of the household.

\section{CONCLUSION AND RECOMMENDATIONS}

The results show that the extension intensity did not seem to have played an important role in the level of income of the households that raised and sold sheep. While this is a reflection of the fact that the existing extension services are delivered to groups rather than individual farmers, whereas farming occurs at the individual level, it is probable that this result is a measurement problem. Sheep producers responded to question as to how frequently they were visited by the extension officers and it turned out that two groups emerged as monthly and annually. It is possible that a different way of interrogation which quantifies the extension engagement might have a different outcome than the one elicited by the binary response. However, it reveals a larger problem of the weakness of the group extension method which may not directly address individual production problems which require a focused intervention. Therefore, the study recommends the use of other extension methods, such as face-to-face interactions, demonstrations, and more frequent visits by the extension officers, which would improve the extension effects. On the methodological side, it is recommended to explore and apply approaches that quantify the extension input that will distinguish between varying levels of intensities of this vital resource.

\section{REFERENCES}

ABDU-RAHEEM, K.A., 2015. Exploring the role of agricultural extension in promoting biodiversity conservation in Kwazulu Natal. Agroecol. Sust. Food, 38(9):1015-1032.

ANDERSON, J.R. \& FEDER, G., 2004. Agricultural extension: Good intentions and hard realities. World Bank Res. Obs., 19(1):41-60. 
ARIYO, O.C., ARIYO, M.O., OKELOLA, O.E., AASA, O.S., AWOTIDE, O.G., AARON, A.J. \& ONI, O. B., 2013. Assessment of the role of mass media in the dissemination of agricultural technologies among farmers in Kaduna North Local Government Area of Kaduna State, Nigeria. J. Biol. Agric. Healthc., 3(6):19-28.

BETTENCOURT, E.M.V., TILMAN, M., HENRIQUES, P.D.D.S., NARCISO, V. \& CARVALHO, M.L.D.S., 2013. The economic and sociocultural role of livestock in the wellbeing of rural communities of Timor-Leste. CEFAGE-UE Working paper No. 2013/01.

BITZER, V., 2016. Incentives for enhanced performance of agricultural extension systems. KIT Working Paper No. 2016/6.

CAWLEY, A.P., HEANUE, K., O’DONOGHUE, C. \& SHEEHAN, M., 2015. The impact of extension services on farm level outcomes: An instrumental variable approach. 150th EAAE Seminar 'The spatial dimension in analysing the linkages between agriculture, rural development and the environment', Edinburgh, UK, October 22-23, pp: 22-23.

CHERDCHUCHAI, S. \& OTSUKA, K., 2006. Rural income dynamics and poverty reduction in Thai villages from 1987 to 2004. Agric. Econ., 35:409-423.

CLOETE, S.W.P., OLIVIER, J.J., SANDENBERGH, L. \& SNYMAN, M.A., 2014. The adaption of the South Africa sheep industry to new trends in animal breeding and genetics: A review. S. Afr. J. Anim. Sci., 44(4):307-321.

KIMARO, P.J., TOWO, N.N. \& MOSHI, B.H., 2015. Determinants of rural youth's participation in agricultural activities: The case of Kahe East Ward in Moshi rural district, Tanzania. Int. J. Economics, Commerce, Manag., 3(2):1-47.

LÄPPLE, D. \& HENNESSY, T., 2014. Exploring the role of incentives in agricultural extension programs. Appl. Econ. Perspect. Policy, 37(3):403-417.

MAKAPELA, M., 2015. Effectiveness of agricultural extension organisation in rural areas: the case of Amathole District Municipality, Eastern Cape. MSc Thesis, University of South Africa.

MAPILIYAO, L., 2010. Sheep production practices, flock dynamics, body condition and weight variation in two ecologically different resource poor communal farming systems. MSc Thesis, University of Fort Hare.

MMBENGWA, V., NYHODO, B., MYEKI, L., NGETHU, X. \& VAN SCHALKWYK, H.V., 2015. Communal livestock farming in South Africa: Does this farming system create jobs for poverty stricken rural areas? Sylwan, 159(10):179-192.

MUNYAI, F.R., 2012. An evaluation of socio-economic and biophysical aspects of smallscale livestock system based on a case study from Limpopo Province: Muduluni village. PhD Thesis, University of the Free State. 
S. Afr. J. Agric. Ext.

Vol. 47 No. 1, 2019: 54 - 60

http://dx.doi.org/10.17159/2413-3221/2019/v47n1a489
Ngqulana \& Obi

(License: CC BY 4.0)

MUSEMWA, L., MUSHUNJE, A., CHIMOYO, F., FRASER, G., MAPIYE, C. \& MUCHENJE, V., 2008. Nguni cattle marketing constraints and opportunities in the communal areas of South Africa: Review. Afr. J. Agric. Res., 3(4):239-245.

MWANGI, M. \& KARIUKI, S., 2015. Factors determining adoption of new agricultural technology by smallholder farmers in developing countries. Journal of Economics and Sustainable Development, 6(5):208-216.

NTSHANGASE, N.L., MUROYIWA, B. \& SIBANDA, M., 2018. Farmers' perceptions and factors influencing the adoption of no-till conservation agriculture by small-scale farmers in Zashuke, KwaZulu-Natal Province. Sustainability, 10(2):555.

OKUNADE, O.E., 2007. Effectiveness of extension teaching methods in acquiring knowledge, skill and attitude by women farmers in Osun State. J. Appl. Sci. Res., 3(4):282-286.

RANDOLPH, T.F., SCHELLING, E., GRACE, D., NICHOLSON, C.F., LEROY, J.L., COLE, D.C., DEMMENT, M.W., OMORE, A., ZINSSTAG, J. \& RUEL, M., 2007. Invited review: Role of livestock in human nutrition and health for poverty reduction in developing countries. J. Animal Sci., 85(11):2788-2800.

RUST, J.M. \& RUST, T., 2013. Climate change and livestock production: A review with emphasis on Africa. S. Afri. J. Anim. Sci., 43(3):255-267.

SWANEPOEL, F., STROEBEL, A. \& MOYO, S., 2010. The role of livestock in developing communities: Enhancing multifunctionality. University of the Free State and CTA.

VAN NIEKERK, J.A., STROEBEL, A., VAN ROOYEN, C.J., WHITFIELD, K.P. \& SWANEPOEL, F.C.J., 2011. Towards redesigning the agricultural extension service in South Africa: Views and proposals of extensionists in the Eastern Cape. S. Afri. J. Agric. Ext., 39(2):57-68.

ZWANE, E.M., 2012. Does extension have a role to play in rural development? S. Afri. $J$. Agric. Ext., 40(1):16-24. 